\title{
LITERATURA PATRYSTYCZNA W POLSCE W OKRESIE ODRODZENIA
}

\author{
I. Warunk1 rozwoju
}

N1e mamy Jak dotąd historil patrologil polsce, niemniej jednak w Juz istniejacyoh szkłcach z tego zakresu w sposób szczególny wyrózniany jest okres odrodzenia ${ }^{1}$. Z wielu waględón okres ten zasługuje na blizsza uwage, jednakze w artykule niniejszym sprébujemy okrésl1é jedynie warunk1, w jakich następowal rozwój znajomośo1 pism ojców Kościoła u nas w okresie Odrodzenta, blorąc pod uwage ówczesne prady 1 wydarzenia w Ich zwiazkach z literatura patrystyczna ${ }^{2}$.

Mimo ze $w$ okresie odrodzenta nastapiły liczno przemiany $w$ zyolu umysłowym, to jednak pradem wiodiacym byz wówczas humanizm. I choclaz kilkakrotnie zaznaczyl sie on juz przed 1 po okresio odrodzenia, to jednak nigdy tak wszechstronnie nie wpłyniz na rozwój kultury, jak waśnie wtedy. Humanizm nie wypełnia całych ram odrodzenia 1 n1e może z okresem tym byé 1dentyeikowany ${ }^{3}$. Termin "humanizm" oznacza głównie prąd umysłowy, poszukujący 1 rozwijający tradycje starozytnej wiedzy o ozlowieku, zawartej w Plozoril 1 literaturze*. Największa więc role odegrał humanizm $w$ dziejach myśli 1 piśmiennictwa, gdyz czerpiac swe 1dee ze starozytnej spuścizny grecko-rzymskiej,

1 Por. A.Bober, Wkład Jezuitón do polskiej patrystyki, w: Studia 1 teksty patrystyczne, Kraków 1967, 177-192; A. Bober, lik lad nauk1 polskiej do badań nad antyk1em chrzécijańskin, STV 0/1971/ 21-50; J.Fijałek, Przekłady pism św.Grzegorza z Nazjanzu w Polsce. Wiadomoś é bibliograficzna 1 patrystyczna, PS 1/1918/46-144 1 3/1919/126-207; J.M.Szymusiak, Zarys dziejów patrystyk1, w: $D_{210-}$ Je teologil katolickiej w Polsce, Lublin 1970, t.3, 81-193.

2 Korzystano przy tym równiez z bibliografil: J.Czerniatowicz, Cz.Mazur, Rocopcja antyku chrześljanskiego polsce. Materialy bibliograficzne, t.1:XV-XVIII w. Cz.1: Autorzy 1 teksty, Lublin 1978; zob. takżo: Cz.Mazur, Literatura patrystyczna w Polsce w okresie Odrodzenta, "Suinmarium. Sprawozdania Towarzystwa Naukowogo KUL" $\mathrm{nr} 5 / 25 / \mathrm{za}$ rok 1978, Lublin 1978, 17-22/streszczenio referatu/.

3 J.Z1omek, Renesans, Yarszawa 1980, 16.

4 S.Lempicki, Renesans 1 humanizm w Polsce, w: Kultura staropolska, Kraków 1932, 205-238. 
przez swój zwrot do literatury 1 kultury klasyoznej, zmiental 1stniejące ideały naukowo-literackie i zastępował je nowym, opartymi na tradycjach starozytnych. Pojęcie humanizmu renesansowego wyraza podwójną trość: 1/ zwrot do człowleka, skuplenie uwagl na wzorach, celach 1 sprawach ludzkiego zycia, 2/ znajomość starozytnej tradycj1 w dziedzinte nauk1 1 śwladomą jej kontynuację. Niosąo ze sobą odro-dzenie studiów nad pomnikaml starozytnej kultury, zwrot do antyku 1 kultu starozytnoácl, przyczynil ole równiez humanizm do odrodzenla studiów nad literatura patrystyczna. Coraz ozéściej siegano do wypowedzi 0jcow Kośc1oła. Jednocześnie l1teratura patrystyczna ó nurt humanistyczny wzmagała 1 umacniała. Jak stwierdza bow1em T.B1eńkowsk1, chodziło tu "nie tyle o solidarność z poglądami wozesnych pisarzy chrześc1jańskich, 1lo o znaleziente waściwej płaszczyzny pogodzenia 1 zblizenia dwóch wielkich tradyojl europejskiej kultury - antycznej pogańskiej 1 chrześcijańskioj. Dla humanistów była to nie tylko potrzeba /Jak w przypadku nlektórych/ wynikajaca z $1 \mathrm{ch}$ zarliwej wiary 1 religijności, ale równiez konteczność zyciowa znalezienta odpowiedn1ej wag1 1 rangl argument 6 w bronlacych tradycje antyczna przed rzoczywistym1 oraz potencjalnyml zarzutani moralistów 1 teologów. Argumenty takie znalezl1 p literaturze patrystycznej 1 zalnteresowanie nia XV 1 XVI w. Waśnie w ty aspekcie nie było przypadkowe. Dazzente do pogodzenia tradyoj1 antycznej z chrześc1jaristwem /.../ było jedna z doniosłych 1 niewatpliwyoh - nie podwazanych juz obeonie przez badaczy - tendencj1 w renesansowej recepcj1 antykun 5 . Nie mozna jednak humanizmu ostro przecimstawlá́ średniowleczu, gdyz éredniowlecze równiez zachowało pewne dobra literatury starozytnej ${ }^{6}$, w tym 1 patrystycznej.

Nauka renesansu opierała się na trzech źródłach: rozumie, dośmadczeniu 1 autoryteole. Mimo zmian kontynuowane jednak były tradycje scholastyk1. Erudyoja humanist $\delta$ wakazywaka przede wszystkim odwolywante się do wypowiedzi autorów reprezentująoych ró́ze kierunk1 mý́lowe. Nowościa było bezpośrednie sięgnięcie do spuścizny ojcón

5 T.Bleńkowsk1, Antyk w literaturze 1 kulturze staropolskiej /14501750/, Wrocław 1976, 24-25.

6 P.llybick1, Odrodzente, w: Historia nauki polskiej, Wrockaw 1970, t. 1, 198 . 
greckich. Bardziej elastyczna postawe wykazywano wobec autorytet 6 , do których zaczęto sie odnosié krytyczn1e. Tak, np. Kopernik podchodził krytycznio do niektórych twierdzeŕ fizyków staró̀ytnych 1 pisarzy wczesnochrześc1jańskich, m.1n. do Laktancjusza. Nowa tez tendencja była dąznó́ó do sprawdzanla autorytetów w sensio pilologicznyin 1 krytycznofilozoficznym. Wybitnym jej przedstawicielem byz Erazm z Rotterdanu, którogo działalność zaznaczyła sie szczególnie w dziedzinie wydań tekstór 0jców Kościoła ${ }^{\top}$. W doble Renesansu najwiz̨cej zmian zaszło zakresio fllologil. Humaniści-p1lolodzy zajmowal1 s1e róźnorodna działalnościa, Jak np. poszukiwaniem nieznanych tekstów autorów starozytnych, krytykq tekstów, studiami nad 1ch forma 1 treścla oraz przekładaml. Wydobyto wówozas wiele dzieł pí́miennictwa starozytnego, tym 1 patrystycznego, które były całkowicio zapomniane bądź nieznane.

Przedmiotem zasadniczym nauk fllologicznych w okresie odrodzenia były 11teratura 1 Jezyk1: racińsk1, greck1 1 hobrajsk1. Znajomośc tego ostatniego postulowali glównie humaniści interesujący sie b1blistykq. Jednakze wraz z rozwojem biblistyk1 rodzilo sie zapotrzebowanie na egzegetyczne teksty 0jców. Wszelk1e zainteresowan1a naukowe w dzledzinie filologil, zgodnie z ogólnym dazzeniem epoki, skupialy sie zasadniczo wokó filologil klasycznej, a w jej obrębio - głównie woḱ́l latynistyki. Humanizm, jeśl1 1dz1e o Jezyk laciński, zapoczatkował szersze zalnteresowanie sie lacískimi autoram starotytnymi, a takzo nowyml sposobam1 interpretacji $1 \mathrm{ch}$ dzieł ${ }^{8}$. To odrodzente laciny klasycznej znalazło odbicie równiez 1 u pisarzy polskich. Aczkolwiek, Jeśli ldzle o Pllologie lacińską, brak jest wolscow tym czasie większych oslągnięó ściśle naukowych /ograniczano sie przewaznio do znajomości jezyka 1 literatury/, to rozległość 1 powszeohna znajomoś6 łaciny, Polsce wywoływała zachwyty cjoych P1lologów humantstycznych ${ }^{9}$. Szczególne znaczenie dla rozwoju języka laolńskiego miały przekłady z jezzya greckiego, m.1n. pism 0jców greckich, skutkiem czego jezyk laciński przyswajał sobie 1 wytwarzał

\section{T Tamze 255-256.}

8 Tamze 372.

9 J.Krókowsk1, Język 1 pí́miennictwo lac1ńsk1e w Polsce XVI wieku, Kultura staropolska, Krakón 1932, 425. 
nowe pojęcia 1 terminy, szczególnie teologiczne. Chociaz w 2. poł. XVI w. Język laciński zaczał tracić w zwizzku z rozwojem piómiennictwa polskiego swe uprzywilejowane stanowisko, to jednak pozostawał nadal językiem nauk1 1 literatury, utrzymujqo przez to kontakt naukowy Polski z Europą ${ }^{10}$. Zajmowano się u nas równiez 1 Kacíńsimi tekstam1 patrystycznym1. Jeśl1 1dz1e o wydania tekstów to były to przewaznle przedruk1 wydań Erazmowych. Większe natomiast ozywiente zaznaczało się w tłumaczentach na język polsk1. Przetłumaczono wówczas "Pro catholica Pldel antiquitate et universitate" Winoentego z Lerynu"11, "Regule" św.Benedykta razem z II Ksiega "Dialogón" Grzegorza Wielkiego 12 , "Listy" św.Hieronima13 1 inne, dotychozas nie tłumaczone utwory patrystyczne.

Znajomość łaciny n1e była wyłqcanym 1deałem 1 celem humantstów. Obok niej coraz bardziej wysuwa sie dazente do poznania nie znanego dotad $w$ Polsce jezyka 1 literatury starozytnej Grecj1. ZaInteresowanie językiem greokim szło do nas głównie z Włoch. Kraj ten stal oie centrum hellenistyki dzięk1 temu, ze po zdobyciu Konstantynopola przez Turków w 1453 r., waśnie do Ital11 przybyl1 uozeni b1zantyjscy przywozac ze sobq wiele cennych rękopisów greckich, w tym zapewne 1 patrystycznych. Humanífci nasi, zaznajamiając sie podczas swolch studiów we Włoszech z jezykiem l literatura grecka zaszczepla11 po powrocie te zainteresowania wraju. Poczatión recepcji hellenlstyk1 wolsce moźna by szukaó juz w połowle IV w., jednakzo dopiero działalność Silviusa Siculusa a Nata, przybyłogo do Polski

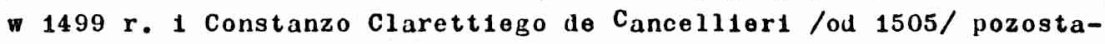
wila głęszze ślady. Do $1511 \mathrm{r}$. nauczali on1 Akademil Krakowskiej, od $1520 \mathrm{r}$. zaś grek1 zaczał uczyé juz rodzimy Lauczyciel - Jerzy Liban ze Slazka. Jednakże jego dzlalalność, przypadajqoa na okres wystapienla Lutra, spotkala sig z gwałtowna kontrakeja. Upatrywano bow gleznie występowano przeciw jej nauczaniu. W alceji tej szczególnie odznaczył sie Grzegorz Paweł z Szamotuł. Z powodu jego wystapień J.Liban musial przerwaé nauczante, grek1, a w 1522 r., na zyczenie

10 Tamze 385-386.

11 J.Czorniatowicz, Cz.jazur, Neoepcja antyku chrześcijańskiego w Polsce, dz.cyt., poz.486/dalej oznaczona skrótem: Kecepcja.../.

12 Tanze, poz.189.

13 Taiże, poz.322,323. 
maglstratu miasta Krakowa, przejéć na "emeryturę". Grzegorz Pawez swej dzlałalnó́ol nle ograniczył tylko w stosunku do Libana. Po przeniesientu sie do Poznania równiez 1 tam ostro wystapil przeciwko nauczającemu greki Krzysztofowi Hegendorfinowi, tak ze 1 ten mustat przerwać jej nauczanie ${ }^{14}$. Trud J.Libana nie okazał sie jednak daremny. Wółroczu zimowym $1526 \mathrm{r}$. Wykłady hellenistyk1 w Akademil Krakowskiej podjel1 jego uczniowle - Sebastian Steinhoffer z Halle 1 Antoni z Napachania ${ }^{15}$. Wkrótce, dzig̨k1 zablegom biskupa krakowskiego Plotra Tomickiego, do wykładów Języka greckiego w 1528 r. powróoli J.Liban. W tym samym roku oflarowaz on Tomickienu sporzązona przez siebie pierwsza w Polsce grecka antologie patrystyczna zism Grzegorza z Nazjanzu, Bazylego Wielkiego 1 Jana Chryzostoma ${ }^{16}$.

Po przełamantu hamujących tendencj1 wakresie nauczanta jezyka greckiego nastạpił rozwój jego znajomośc1, zależny teraz juz tylko od poszczególnyoh wykładowców. Prawie wszyscy humaní́c1, czynnl na polu grecystyk1, wpłynęli równiez na rozwój zainteresowán 11teratura patrystyozna. W swych studiach nad literatura greoka siegali równiez do tekstów patrystycznyoh, a przez tłumaczonia propagowal1 u nas mý́l Ojców greckioh. Stan1sław Hozjusz/1504-1579/, póznlej8zy biskup warmińsk1 1 kardynaz; zaznajomiwszy sie pod kierunkiem Libana z Jezykiem greckim, zajaz sie poczatkowo greckimi klasykami, leoz wkrótco zalnteresowal sie tekstami greckich 0joów Kościoła. W $1528 \mathrm{r}$. wydaz Wrakow 1 e po grecku z wasnym tłumaczeniem kac1ńakim homilie Jana Chryaostoma pt. "L1bollus elegans in quo confert verum monachorum oum prinoiplbus, divitibus ac nobllibus non hulus mund $1^{17}$. Byz to drugi druk greoki wydany $w$ kraju a pierwazy patrystyozny ze wschodnich OJcóm Kościoła". Równiez w owej "Confession wydanej Krakowie 1553 r. ogłosil Hozjusz po greoku czwarta katecho-

14 J.Czorniatowioz, Poczatki greoyetyki 1 walka o jozyk grecki - Polsce doby Odrodzenia, : Studia 1 Materialy z Dziejów Nauk1 Polskiej, Warszawa 1959, Seria A, z.3, 27-28,34-36,48.

15 H,Baryoz, Historla Uniwersytetu Jagiellonskiego $w$ epoce humanizmu, Kraków 1935, 81-82.

16 J.Fijałek, Przekłady pism áw.Grzegorza z Nazjanzu p Polsce, PS $1 / 1918 / 48,78$. Nie została ona jednak wydrukowana, obecnie zaś katalogi rękopisóv nie notuja juz tej antologi1.

17 Recepoja...., poz.356.

18 J.Czerniatowicz, Poczatki greoystyk1..., dz.cyt., 44. 
zę mystagogiczną Jana Chryzostoma. Jakkolwiek z racj1 sprawowanych funkcji kościelnych nie mógł Hozjusz oddawá́ slę studiom patrystycznym, to jednak odegrał duza role propagowantu mý́ll ojców. Rzeoz zrozumiała, ze 1 we wasnych pracach obflole korzystał z 1 ch plsm ${ }^{19}$. Równiez działalność Marcina Kromera/1512-1589/przyniosła owoce na polu patrologi1. Jego Immatrykulacja na Un1wersytecie Krakowsk1m /31 VII $1528 \mathrm{r} . /$ przypadła na czas powrotu J.L1bana do wykładów Jegrecklego. Po uzyskaniu bakalaureatu sztuk wyzwolonyoh w $1530 \mathrm{r}$. wyjechał na studia do Włoch. W ozasie pobytu wolonil odnalazł wekopisie homilie Jana Chryzostoma, z których częś́ wydal po powrocie do kraju, tłumacząc je równlez na język lacínski. Następnie przekład tych homil11 opublikowany zostal w $1550 \mathrm{r}$. Moguncj1, a $1552 \mathrm{r}$. ukazały sie one wazyle1 razem z tekstem greckim ${ }^{20}$. Wydanie to przyniosło M.Kromerow sławe miedzynarodowa. Ponadto, Jak stwierdza H. Baryez, publikacja ta stanowiła "wazne ogniwo w tworzeniu sie polskiej teologil humanistycznej opartej treściowo 1 co do formy na 11teraturzo patrystycznej"21. Niemała role woznawaniu greckich ojcó Kościoła odegrał również Stanisław Grzebsk1/1524-1570/, najznakomitszy polski hollenista XVI wieku. W Ilpcu $1564 \mathrm{r}$. oflarowat on Hozju-. szow 1 "Duo poemata" Grzegorza z Nazjanzu, wydane druk1em 1565 roku. Plerwsy poemat wydany został w oryginale greckim wraz z trumaczentem zacísk 1m, drug1 zaś jedynie tłumaczenlu zacískim ${ }^{22}$. Ponadto dokonal Grzebsk1 przekładu na Języ polsk1 innego poematu Grzegorza "o ułomności natury ludzkiejn23. Przekład ten nio ukazal sie jednak wówozas drukiem. Spósród Innych grecystów tego okresu zasłuzyl1 ale dla patrologli szczególnie J.Grodeok1/+1574/ wydawoa 1 tłumacz katechez Cyryla Jerozolimskiego ${ }^{24}$, Stanisław Iłowski /+ 1589/tłumacz na Jezyk zaciński dzieł Synezjusza z Cyreny ${ }^{25}$ Bazylego Wielkiego 26 oraz Fabian B1rkowsk1 /+ 1636/ wydawca greckiogo tekstu "Listón" Ignacego Ant1o-

19 W. Urban, Hozjusz Stanisław, PSB X 42-46.

20 liecepcja..., poz.330-32.

21 H.Barycz, Kromer Marcin, PSB XV 319-325.

22 Recepcja..., poz.303.

23 H.Barycz, Grzebsk1 Stanisław, PSB IX 99-102.

24 Recepcja..., goz.273-285.

25 Tamze, poz.481.

26 Tainie, poz.150-153. 
cheńskiego, z masna, obszerna przedmową 27.

Dla rozmoju zainteresowán literatura patrystyczna wazna była równiez inna tendenoja humanistyezna - rozwój Języów narodomych. Odrodzenie, okres ozywionych gtudiów nad Jezykami klasycznymi, zaznaczyz. sie rozwojom literatur narodowyoh. Polsce, dzieki temu rozwojow1, wiek XVI uzyskal miano złotego wioku ${ }^{28}$. Pisarze renesansowi uczynili język polski jezykiem pímiennictwa, językiem literackim. Przekłady \$ Jezyka lacínskiego 1 grecklego wpływały równiez na rozwój Języka polskiego popxzez zastosowanie nowyoh form 1 tré́c1. Wazny byz tu równiez wplyw reformaoj1. Posługiwano sie jęrykami narodowymi dla propagowanla nowych wyznan wéród najszergzyoh warstw społecznych. Kościól poozul a rónntez zmuszony do chwycenta za te sama bron, utwierdzajac deleki talentow1 1 autorytotowi ewych p1sarzy stanowisko jezyka ojozystego w pí́miennictwie. Na rozwój języka polskiego mpłynęły znacznie przakłady tekstów patryatyoznych, dziek1 czemu języku ojczystym zaozęto wyrazad́ tresol toologiczne. Tak wegc do rozwoju jezyka polskiego przyczyniaxy sie humanizm, który damal pierwaze impulsy oraz reformacja, która ten proces przyspioszyła ${ }^{29}$. Tendeneja ta miała rómniez duzo maczenio dla patrystyki. Pojawizy sie wtedy plerwsze przekłady na języ polski plom ojoów Kościoła 1 pisarzy wozesnochrzé́cijariskioh tak greckich, jak 1 zacińskich ${ }^{30}$. Myśl patrystyczna stawała sie więo ooraz powszechniej znana, takze wáród lửzi nle znających jezyków oryginalnych tych tekstóm.

Humantzm epoki renesansu pyrazak sie nle tylko pilologil, dooteral równiez 1 de teologil. Ponjewaz teologia dredniowieczna skuplała swoje zalnteresowanla głównle na doolekaniach spekulatywnych, dlatego tez zainteresowanto 0jeami było wtedy nikłe 1 nie przyniosło na polu patrologii znaczniejgzych osiagniéd. Zmiana nastapiIa tu dopiero okresio odrodzenta, m.1n. dzięi humanistom ${ }^{31}$. Ilumaniatyozne prady, jakie zaczęly powoll przenikać 1 do teologil, zaz-

27 Recepcja..., poz.329.

28 P.llybick $1, \mathrm{dz}, \mathrm{cyt}, \mathrm{372-373.}$

29 J.Krók owaki, dz,cyt, , $394,454,385$.

30 Reoepeja..., poz.189,264,265,322,323,459,466,486,530.

31 A.Bober, Wkkad jezuitów do polskiej patrystyki, dz.cyt., 177. 
naczyły sie z jednej strony odwrotem od dotychczasowego ujmowania problemów metodaz dialektycznaz, z druglej zaś zwrotem do źródeł 1 podstaw nauki katolickiej, tj. do Pisma św. 1 ojców Kościoła. Duze zasługi na tym polu połozył Erazm z Rotterdamu. Był on znakomitym wzorem humanisty, łączącego zainteresowanta toologiczne z filologioznymi. Poprzez wydante oryginalnego tekstu Nowego Testamentu, który wraz z Własnym przekładem łacłńsk1m ogłos1ł w Bazyle1 w 1516 r., a takze wydawanie plsm Ojców Kościoła, szczególnte św.H1eronima, stał sie Erazm wzorem naukowego studium teologil owych czasów rómnieź dla polskich uczonych ${ }^{32}$. Jego zasług1 dla patrologil sa tak ogromne, że można go wlaściw1e nazwać twórca nowozytnej patrologi1, gdyz znalazł wóród osób grupujących się jego kręgu wielu naśladowców 33 . Juz w początkaoh XVI w. drukowano u nas jego opracowania plam ojców Koścıła. IV 151811519 r. przedrukowano wrakow1e wydane przezeń niektóre listy św.Hieronima34, a 1528 r. "De beato Philogonio" Jana Chryzostoma ${ }^{35}$. Jak stwierdzil J.Fijałek, z tymi pierwszym1 drukam1 patrystycznym1 Erazma u nas maczynaja sie pojawiaó plerwsze zwiqzk1 1 przesłank1 studlum patrystycznego, spojonego nierozdzielnie z imieniem Erazma"36. 0 zwiazkach Erazma z Polska śladczyć może równiez fakt zakupu jego ksiegozbioru przez Jana Laskiego Młodszego, z pozostawieniem mu go w dozywotnie użytkowanie. Póńniej po ksiegozbiór.ten jeździl do Bazylei Andrzej Fryoz Modrzewski ${ }^{37}$. Wielu Polaków zetknawszy s1e z Erazmem bezpośrednio stało sie pózniej goracymi propagatorami jego osoby 1 myśl1 kraju, nywierająo równiez wpływ 1 na rozwój zalnteresowań patrystycznych ${ }^{38}$.

$\mathrm{Na}$ nowy, humanistyczny nurt w teologit nio pozostawal gluchy równiez 1 krakowski frydzial Teologiczny. Juz w trzecim dziesięcioleciu XVI w. zaczęto tu sporadycznie prowadzić mykłady z teologil biblijnej. Pełny jednak rozkwit humanistyczny, który prezentowall

32 H. Barycz, H1storia..., dz.cyt., 176.

33 J.Fijałek, PS $1 / 1918 / 78-79$.

34 Recepcja...., poz.313,320.

35 Recepcja.... poz.338.

36 J.Fijałek, PS $1 / 1918 / 113-114$.

37 J.Z1omek, dz.cyt., 36,179.

38 H. Barycz, Sladami Erazma z Rotterdamu w Polsce. W 5000-1ocio urodzin wielkiego humanisty, w tegoz: $z$ epoki renesansu, reformacjI 1 baroku. Prądy - 1de0 - ludzie - ks1azk1, Warszawa 1971, 7-41. 
taoy teologowie Jak Mateusz z Kościana, Benedykt z Koźmina, Antoni z Napachania, Wojc1ech Nowopolozyk czy późnłej Stantsław Sokołowski, nastapił w teologil dopiero w poł. XVI wioku ${ }^{39}$. Szczególne znaczenie miała tu działalnośc, Jaką rozwinał Stanisław Hozjusz, największy teolog owych czasów. Oplerała sie ona bowiem na nowych nurtach w toolog11, a jego przykład pociaggał innych. Wskazywano na potrzebe poznania myśli wschodñch 0jców Koścloła jako nowego źródła myśl1 rel1gijnej 1 argumentacji teologicznej. Podkreślano równiez pokrewieństwo filozoficznoj myśl1 greckiej z doktryna chrześc1jańska. Jako argument wysuivano tu myśl św.H1eronima, który uwazał znajomośó autorów klasycznych za konteczne przygotowante do studiów teologleznych. Duze znaczente miała tu równiez mowa áw,Bazylego "0 pozytku z czytania dziel pogańskich". Nowy ten prad w teologi1, przejawiajacy sie głównie szerszym 1 bezpó́rodnim zwrocie do źródeł, tj. do Pisma ów. 1 0jeów Kościoła, równiez d la rozwoju znajomości literatury patrystycznej otworzył nowe, duże mozliwośc1.

Okres Odrodzenia byl zarazem doba reformacj1. Nie była to zbieźność tylko czasowa czy przypadkowa. Między tyni obydwoma prądam1, ogólnokulturalnym 1 religijnym 1stniały wewnętrzne zwiłzzi. Przedstawicielom reformacj1 1 humanistom wspólna była tendencja badania 1 krytyki tekstóm religijnych /szczególnio Pisma ów. 1 pism ojców Kościoła/, Jako źródła wiary 1 wiedzy rellgijnoj. Nowośc1a roformacj1 była dazzność do zupelnej swobody interpretacjl tekstów biblijnych ${ }^{40}$. Prowadziło to do wytworzenia sie wielu stanowisk w rónych kwestiach, m.1n. odnośnie do roll i znaczenia literatury patrystycznej. Takze wonte samego ruchu reformacyjnego powstawaly coraz to wieksze rozbleźności. Wgzystk1e zaś kierunki reformacyjne poprzez polemiki religijne wnosiky głębok1 ferment w zycle umyszowe narodu. W dyskusjach tyoh ogniskujących sie wokó zagadnien religijno-dogmatycznych 1 organizacyjno-kościelnyoh, literature patrystyozna wykorzystywary jako argument zarówno rótne odłamy reformatorów, Jak 1 kręg1 katolickie. Cała literature polemiozna 1 agitacyjna starano sie oprzeć nie tylko na materiale biblijnym, lecz równiez 1 na patrystycznym. Zwiększało s1ę dzięki temu zainteresowante pismañ ojeón Kościola, a wykorzys-

39 H.Baryoz, Historia..., dz.cyt., 175-176.

40 P.Rybicki, dz.cyt., 202. 
tywante 1ch pism przez protestantów wynikało z różnch przyczyn 1 przejawiało się róznym stopniu. I tak, np. Marcin Luter, który w latach 1515-1527 był welkim entuzjastą sw. Augustyna, dostrzegłszy - następnym okresie swej dzlałalnosol zasadnicze róznice dzlelące jego poglądy od nauki b́.Augustyna, starał sie je coraz bardziej łagodzić ze względów agitacyjnych. Równiez Kalwin zaczerpnąz od éw. Augustyna swój teocentryzm 1 walkę z odradzającym się pelagianizmem $^{41}$. Stosunek do literatury patrystyoznej przywódców reformacji przejmowali polscy protestanci. I ohooiazwyrocznia dla nich by Luter, to jednak ze względów polemicznych 1 ag1tacyjnyoh, tam, gdz1e Im to odpowiadało, powoływali sie na pisma 0jców Kościoła ${ }^{42}$. Tak wiego pisma 0jców Kościoła wolagnieto do polemiki protestanckiej. Wyrazem tego był, m.1n. przekład "Dialogu z zydem Tryfonem" św.Justyna dokonany przez W.Krzyszkowskiego $1 \mathrm{Sz}$.Budnego 1564 roku $^{43}$. Polemik1 z protestantami pobudzały strone katolicka do wiekszego zainteresowania sie pismami patrystycznymi. Strona katolioka zajmomala począkowo polemice stanowisko obronne odpierajac zarzuty w oparciu o Pisino św. 1 tradycje, a więc o pisma ojeów Kościoła. Późntej ton katolicki się odmienił, stał się bardziej aktywny, na postępy reformacji zwracano większa uwage, równiez w pracy kaznodziejskiej ${ }^{44}$. Wyrazem wykorzystywania tradycji patrystycznej polemice religijnej był takze fakt nadawania róznowiercom nazw zaczerpnį̧tych ze starozytnośc1 chrześc1jaĺskiej. I tak, np. braci polskich, poniewaz podwazali dogmat o Trójcy św. przez analogie do herezj1 z IV w. nazywano arianami samosaté́czykami lub ebionitam. Heprezentantem ówczesnego stanowiska strony katolickiej w odniesientu do 0jców był.kardynał Ilozjusz. Chociaz niektórych ojców nie uwazał on za nieomylnych i dostrzegal u nich błędy, to jednak, za wskazaniem Wincentego z Lerynu, kładł silny nacisk na $1 \mathrm{ch}$ wspólny autorytet, stwierdzając w nich 1 przez niah prawdıiwość wiary. Przedstawicielem innego stanowiska w stosunku do 0jców, różnego od katolickiego 1 protestanckiego, moze byd Andrzej Frycz Modrzewski. Autorytetu Ojców Kościoła nie

41 T. Eborowicz, św.Augustyn, SipP 70.

42 J.F1Jalok, PS 1/1918/119-120.

43 Recepcja..., poz.459.

44 A.Brtickner, Reformacja, w: Kultura staropolska, Kraków 1932, 256-257. 
uznawal, uwazal go za przesadny 1 nieobowiazujący. Twierdz1ł, ze zarówno protestanci, jak 1 katolicy, za wiele powagi przyznaja ojoom Kościoła ${ }^{45}$. Różnorodność stanow1sk w stosunku do autorytetu 0jców mpłynęła równtez pewnym stopniu 1 na koniecznó́ć sformułowania nauk1 o Tradycj1 przez Sobor Trydenck1. Wykorzystywante plam 0jc6w Kościoła polemice religijnej spowodowało walke o właściwe "rozumienie" ioh nauk1. Na polemice tej sama patrystyka mogka tylko zyskac. Przyetapiono bardziej intensywnie do publikacji plsm 0jeów, gdyz wszelka dyskusja merytoryczna musiala oprzed ele na pewnej podstawe tekstualnej ${ }^{46}$. Zainteresowania piśmienniotwem patrystycznym rozbudzone przez humanizm zostały wiec przez reformacje wzmocnione. Połozono tez wejszy nacisk na strone teologiozna mýsll patrystycznej przez wykorzystywanie joj polemice religijnej. Sama zá́ polemika rel1gijna mogła $w$ Polsce swobodnie gie rozwijac, gdyz sprzyjaly temu. dwczesne warunk1 polityozne. Konfederacja warszawaka 1 "pacta conventa" były legalna podstawa działalnośc1 wyznaniowej w Polsce, co zreszta było zjawlekiem wyjątkowym w cazej Europie. Równiez nie boz znaczenia byl tu rozwój szkolnictwa wyznantowego, jak 1 sprowadzente do Polski Jezuitów, których "ratio studiorum" uwzględniało nauki humanistyczne 1 historyczne. Powstajacen myniku reformy trydenokiej seminaria duchowne oraz nowe of́rodki naukowe, tak1e jak Akademia Lubraniskiego - Poznaniu, Akademia Wileńska 1 Akademia vamościu, zapewniały coraz szerszy krąg odbioró́w literatury patrystyoznej.

Reformaoja obok pozytymego wplywu na rozwój literatury patrye¿yoznej wywarła równiez, aczkolwiek pośrednio, wpłyv nogatywny, który przejawil sie na Uniwersyteole Krakowgkim 1 innyoh ówczesnyoh uczelniach katolickioh w Polsco silnyin pradom roakojt przeciw humanizmowi, jako rzekomemu sojusznikow1 1 mspółautorowi rozłamu religifnego. W ten sposób dodatnio impulsy humanizmu dla rozwoju literatury patrystycznej zostaly na pewien czas zahamowane. Pod mplywem reformacjl zaczał znowu dochodzió do głosu prad ocholastyezny. Okres ten trwal jednak krótko 1 został szybko przezwyolezony ${ }^{4}$.

45 J.P1jakak, PS 1/1918/102-103.

46 A.Bober. Whad jezultow do polskiej patrystyk1, dz.oyt., 177.

47 H.Baryoz, Historia..., dz.oyt., 96-97,281. 
Poza zmianami, Jakie przyniosły dla literatury patrystycznej nowy prąd umyskowy/humanizm/ 1 prąd religijny/reformacja/, zaszło równiez okresie Odrodzenia k1lka wydarzeń mających bezpó́redni wpływ na pogłębienie jej znajomośc1. I tak, np. za pontyfikatu papieza Pawla IV obowlazywal w Rzyme zakaz drukowania dziel ojców Koścłoła. Zdumiewał Hozjusza bezsens tego zakazu 1 włánte, by wyriá bró z ręr1 rółnowierców, zablegal ueilnie o podjęcie studiów patrystycznych zarówno w Polsce, jak 1 wzymie. Twierdzil on, ze gdyby studia patrystyczne kw1tły okresie mystapienia Lutra, reformaoja nie wyrzadzilaby az tak wiele zła. Wkrótce jednak, dzięri zabiegom kardynałów Seripando 1 Hozjusza, wezwano krótko przed 1565 r. Pawła Mancyusza z Weneoj1 do lzymu dla drukowania dzieł 0jodw Kośloza. Tak więo z Inlojatywy naszego kardynała zapoczątkowano równ1ez stud1a patrystyczno, samym Rzymie ${ }^{48}$. Wieksze jednak znaczenie dla rozmoju znajomośo1 literatury patrystyoznej, szozegolnie greokiej, mialo przyznanie przez papieza Plusa V tytuzón Doktora Kó́oloza czterem ojcom greckim tj. Atanazemu Wielkieluu, Bazylemu Wielkiemu, Orzegorzow I Nazjanzu oraz Janowi Chryzostomow1 1 mprowadzente eragmentow loh tekstów do modlitw brewlarzowych "Kośo1ele rzymskokatoliokim bulla "Quod a nob1s" a 15 l1pca 1568 roku. Od toj chwill praynajmniej fragnenty p18m tych ojoow znalazky se w oodzionnyoh modiltwach duchownyoh, co wzbudz16 mogło szersze salnteresowante lch spuśolznq p1sarska ${ }^{4}$. Rónniez przencesiente przez papieza Grzegorza XIII 1880 r.

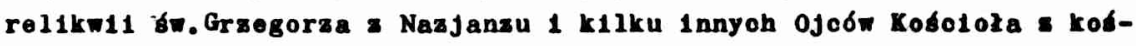
clola benedyktynek na Polu Marsowyn do osobnej kaplioy MP ce watykariek1ej, przez duzy rozglos nadany tym uroczystośolom, griegsayło zalnteresowan1 tyciem 1 twórozośc1a przynajmniej Gragorza z Nazjanzu. Powstazo wtedy wiele okolicznoślowyoh utworów, przewakn1e panegiryków, aozkolw1ek zdarzaky ale 1 prace naukowe 50 . z wydarzeń kośc1elnyoh tego okresu najwięzze jednak znaozenie dla patrystyk1 miał Sobór Trydenok1 /1545-1563/. dekreo1e o kanon1e P1sma ów. na sesj1 $1546 \mathrm{r}$. określono miejsoe tradyojl patrystyoznej $\mid$ stosunku do Pisma sw., natomiast w dekretach sesjl koroowych - stosunek

48 J.F1Jałek, PS $1 / 1918 / 96-97$.

49 J.P1jakek, PS $3 / 1919 / 196$.

so J.Fijalek, PS $1 / 1918 / 51 ; 3 / 1919 / 205$. 
tradyoji patrystyoznej do cakej tradyoj1 kodolelnej ${ }^{51}$. Uchwalenie tych dekretó było mynikiem polemik z protestantaml. Okréslenie miejsoa jednak 1 wagi pism 0je6w Kościoła w całej tradyoj1 kócielnej wpzynezio jeszcze bardziej na rozwój studió patrystyoznyoh. Wazystkie te wydarzenla z zyola Kosoloła powszechnego odbijaty ole tywym echem równiez 1 - Polsoe, wzbudzająo coraz w1ększe zalnteresowanie literatura patrystyouna.

Wyoiu Koscloza w Polsce zaszy takzo pewne wydarzenia majaoe wpływ na rozwój znajomośol literatury patrystycznej. Wyrazem tego moga być uchwaly polskich synodón prowinojonalnyoh. Obydwa welkie synody prowinojonalne, zeczyok1 prymasa Jana Laskiego z 3 lipca 1527 r. 1 plotrkowski prymasa Piotra Gamrata z 17 października 1542 r. zawieraky gtatut o ksiazkach, Jakie powinni mié duchownt pracujacy " duszpasteratwie parafialnym oraz wazysoy kaznodzieje éflecoy 1 zakonni. Aby móc skutecznie głosió Słowo Boze gzosizy odnośne statuty - duchowni winni posiadá́ Pismo óm. a takte, Jé́l1 kto mógz, dzieza święych: Cypriana, Atanazego, Grzegorza * Nazjanzu, Bazylego Wielkiego, Jana Chryzostoma, Hilarego, Augustyna, Hieronima, Grzegorza Wielkiego 1 Leona Wielkiego. J. Pijazek twierdza, to mezystko co mamy wotawodawstwio oynodalnym b1skupów naszych o studium 0jców Kośc1oła lacińskich 1 greck1oh, zanyka sie tym jednym statuole, który zachowal sie nienaruszente 1 w epooe potrydenckiej. Powtarzaja go oba zbiory konstytucj1 synodów prowinojonalnyoh Kośloka motropolitalnego gnieźnieŕskiego /.../ Stanisława Karnkowskiego/1579/ 1 Jana Węzyka/1761 r.//52. Podobne nakazy ozy zalecenta spotkać mozemy równtez $w$ aktach kapituz. I tak, np. Instrukcja kap1tuły poznańskiej na gynod prowlnojonalny plotrkowak1 z $1557 \mathrm{r}$.. migdzy artykukam1, jaki ten synod miak uchwalió, nakazywaka duchowlenstwu wazelkiego stanu mied sawsze pod ręa plsma: Ambrozego, Hieronima, Augustyna, Grzegorza Wielkiego, Loona Wielkiego, Cyryla Aleksandryjskiego, Jana Damascerakiego 1 "im podobnych". Brak jest wym wykazie Grzegorza z Nazjanzu, aezkolwiek jego plema były zalecano w statutach poprzednich synodów/Zø̨ozyok1 1527/. Byó moze, Jak przypuszcza J.F1jałek,

51 S.Plegzozoch, Patrologia, Poznań 1964, 18-19.

52 J.P1Jalek, PS $3 / 1919 / 132$. 
opowodowane to było tym, iz niektóre stwierdzenia Grzegorza z Nazjanzu wykorzystywano wówczas jako argument przeo1w katolikom, a Jan Kochleusz, poznański polemista antyluterański wapale polemioznym 1 gorliwośc1, zaczał znajdowá nawet błędy teologiczne pismach tego Ojca Kościoła ${ }^{53}$. N1ezaleznte od tych zmian w ocente poszczególnyoh ojców, konkretne nakazy nie tylko sprzyjały rozwojowi znajomośc1 11teratury patrystyoznej, lecz wprost zobowiazywały duchownych do ozytania p1sm ojcóm Kościoła.

Wazyatkie te mozlíó́ol, które nibsz ze sobą dla rozmoju 11teratury patrystyoznej nowy okres, mogiy byó wykorzystane gínnie dzlęk1 wprowadzeniu druku. Wynalazek ten, doknnany poozątkach odrodzenta, w istotny sposób zmiental mozliwośl powielania zapisanych wytworó myśli ludzklej. Dzlęk1 drukow1 humanizm mógz wazędzie dooierá́ razem z ksiazka. Ksiazka drukowana gtamała sie czynnikiem umozliwiającym propagowanle wszelkiej literatury, tym rómniez 11teratury patrystycznej. 0 tym, 12 wynalazek druku od awych początkóm wykorzystany zostal do propagowania literatury patryatycznej, 1 ze

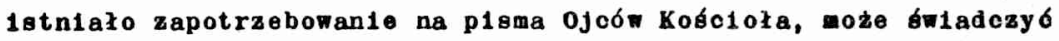
fakt, ze niektórzy drukarze wiánie od pism 0jcón Kościołe rozpoozynal1 swa działalnó́b typograficzną. I tak, np. plerwszym drukiem datowanym a "Moralla in Job" Grzegorza Wielkiego, wydane przez Bertholda Ruspela - Bazyle1 1468 roku ${ }^{54}$. Natomiast plerwszym drukiem w. Oxfordzie było "Bxpositio in Symbolum Apostolorum" śm.Hieronima z 1478 roku $^{55}$. Jedna zás z najpiękniej drukowanych ksiązek $x V$ w. by$1 a$ "De o1vitate De1" śm.Augustyna wydana w $1486 \mathrm{r}$. Abervil1e ${ }^{56}$. Zas trzyetopniowa, piękna ozolonka greoka tzw. "greozyzna królewska" zastosowana została po raz pierwgzy przez R. Etienne'a w 1514 r. do druku "Historia Ecolesiastica" Euzebiusza z Cezarei ${ }^{57}$.

W Polsce mprowadzenie druku zostało rómniez od razu wykorzyetane do propagowania literatury patrystycznej. Plerwazy wodrowny warsz tat drukarski pojawil sie Polsce 1473 roku. Byl to warsatat ba-

53 Tamze 139-140, Zob. równiez: J.M.Szymusiak, Zarys dz1ejó patrystyki, dz.cyt., 73, nota 19 .

54 Encyklopedia Wiedzy O Ksiązce, Wrocław 1971, 2278.

55 Tamze 175312462 .

56 Tamze 747.

G7 Tamze 771. 
warozyka Kaspra Straubego, który przez oztery lata/1474-1478/pracowaz najprawdopodobniej na zanówiente bernardynów krakowsk1 ch ${ }^{58}$. Jednym z czterech jego krakowakich druków były "Opusoula" 6́w.Augustyna, wydane ok. 1476 roku $^{59}$. Natomiast okolo $1477 \mathrm{r}$. ukazaly 81 , najprandopodobniej - Chelmnie nad W18Ia, "Sermones" f́n.Augustyna, tłoozono najprawdopodobniej przez Braci Wspólnego Zycia ${ }^{60}$. W latach 1503-1505 dziakal Krakowie Kasper Hochfeder. Z plerwszego roku Jego produkoj1 poohodz1 "De hebdomad1bus" Booojusza61. Równtez - drukarni Floriana Unglera /+ 1536/, która później prowadziła jego tona Helena, ukazywały s1e druk1 patrystyczne62. Szczególn1e zalagi - wydawaniu literatury patrystycznej pozozyz Hieronim wietor /1480-1546/. Byl to typowy przedstawiolel epok1 Odrodzenta. W $1499 \mathrm{r}$. zostal bakałarzem nauk wyzwolonych w Akadem11 Krakowsk1ej. W $1510 \mathrm{r}$. otmorzyl drukarnie - Wiedniu, utrzymująo nadal szerokie kontakty - Rrakowem, gdz1e 1517 r. załozyl swa druga drukarnie 1 od 1518 r. rozpoczał szeroka działalność drukarsko-wydanntoza. Drukowaz dz1eła autorów klasycznych oraz humanist 6 wolskich ${ }^{63}$. Na uzytek naszych humanistó wydał plerwazy $w$ Polsce druk węzku greckim 1524 roku64: Jego druk1 były bardzo staranne 1 estetyczne. Ogółem wego krakowakiej oftcynte ukazało s18 ok. 328 tytułón, z tego 11 wydaŕ p18m Jana Chryzostoma ${ }^{65}$, 4 wydania piam śm.H1eronima ${ }^{66}$, 3 wydania plsm \&́w.Augustyna ${ }^{67}$, J wydan1a plsm św.Bazylego Wlelk1ego ${ }^{68}$, oraz

58 K.P1ekargk1, Ksiazka w Polsce W XV 1 XVI wieku, w: Kultura staropolska, Kraków 1932, 356. Pierwgzym drukiem $\%$ Polsoe byl kalendarz na rok 1474. Date ta przyjać mozna równiez za poozatek Odrodzenia $\mid$ Polsoe. Zob. rómniez: B.Kooowsk1, Straube Kasper, - i Stownik pracownikó ksiatki polskiej. Praoa zbiorowa pod réd. Ireny Treichel, Warszawa 1972, 859.

59 Recepcja..., poz.25.

60 Recepeja.... poz.463. Zob. rónniez: Z, Nowak, Poozatk1 gztuk1 drukarskiej na Pomorzu WV wieku, Gańsk 1976, 199-214.

61 Recepcja..., poz.250.

62 Recepoja..., poz $.461,483$.

63 U.Bohonos, Wietor Hieronim, w Słownik pracomnikóm ksiazk1 polsk10J, Warszawa 1972, 953-954.

64 J.Cgerniatow1cz, Rola drukarstwa greokiego rozmoju pí́mienniotwa naukowego "Polsoe do pozowy XVII T. Kraḱ́w 1 Zamó́b, W: z dalejow polskiej kultury unysiowes XVI 1 IVII wieku, Trookaw $1976,157-225$.

Recepoja..., poz.334-344.

66 Reopoja..., poz.313,316,317,320.

67 Recepoja..., poz.50,57,63.

68 Reoepoja..., poz.156, $166,166$. 
jedno mydante traktatu fw. Wincentego z Lerynu ${ }^{6 y}$. P1sma Ojcón Kośo1ola tłoczyli równiez inni drukarze Krakowa, Zamościa ozy Wilna. Głónnym ó́rodkiem literatury patrystyoznej był jednak Kraków.

Znane były równiez u nas, w omawianym okresie, p1sma 0jó́ Kościoła 1 pisarzy mezesnochrześc1jarískich mydane poza granicami polsk1. Jednym z głównych czynnikow sprzyjajacych napływowl l1teraturý patrystycznej do Polski byzy podróze, bardzo ozywione w epoo Odrodzenia. Niewielu humanistóv wiazało sie na stałe z jednym ́́rodowiskiem, więk8zó́b odbywająo liczne wędrówk1, opróoz nowych dązer 1 impulsów przymozika ze soba ksiazki. Czynnik sprzyjajacy stanowiza tu równiez welonarodowośs poszczególnych ośrodków naukowych. Wazne byIy nie tylko przyjazdy oboych humanistón do Polsk1, lecz takze nyJazdy Polakó za granice, przewaznie na studia, skad wracajqo praymo2111 ze sobs nowośc1 wydawnicze, m.1n. z l1teratury patrygtyoznej. Swiadoza o tym ówozesne katalogi biblioteozne. Spó́ród uniwersytetów obcyoh, w których najozęściej studiowal1, np. tylko p1sarze polsoy XVI wieku, plerwsze miejsce zajmuja Padwa /69/, Wittenberga /45/ 1 Rzym /41/. Jednakze najwieksze znaczenie dla napkywu literatury patrystycznej do Polski miaky kontakty Polaków z Bazylea /w XVI w. 15 osób/70 Dzięki działalności Erazma z Rotterdamu była bowiem nówozas Bazylea największym ośrodkiem wydawniczym wakresio literatury patrystyoznej.

Na podstawia powyzozych uwag stwierdzid więo mozna, ze okres Odrodzenia stwarzal korzystne warunki dla rozwoju znajomóol literatury patrystycznej Polsce. Humanizm przez swój zwrot do antyku kierował takze uwage na starozytna literature ohrześojjarika. Poprzez rozwoj fllologil laolískiej, a ezczególnte przez rozpoczęo1e nauczania języka greckiego, zostały stworzone mozlimośl bezpośrednlego dotarcia do oryginalnyah tekstó patrystycznych. Tłumaczenla

69 Reopoja..., poz. 487 .

T0 Dane statystyczne na podstawie pracy z.Florozak, Udziaz regionón - kształtowaniu sie pímienniorwa polokiego XVI wieku. studium z zakresu socjologil pisarstwa, Hrookaw 1967, 275-288 oraz mapa nr 5. 
na jezyk polski sprawiały, 1 z literatura patryatyozna docierała takzo do warstw społeoznych, wtórych nie były znane jej oryginalne Jezyki. Podczas gdy humanizm wpływal na rozwój znajomośc1 literatury patrystyoznej głównie przez rozbudzenie zainterescwań filologlcznych, to reformacja, przez wykorzystywanie literatury patrystycznej - polemikach religijnyoh, spowodowała zwrócenie większej uwagi na teologiczna zawartośó tej literatury. Nie bez znaczenia były tu równiez kontakty polskich uczonych z europejskimi osrodk ami naúkowymi. Szczególnie wazna role odegraky zwiazk1 Polaków a Erazmem z Rotterdamu. Fprowadzenie druku do Polski oraz podjęole produkej1 11teratury patrystycznej przez naszych typografów, Jak równiez napływ obcych druków patrystycznych stwarzały techniczne warunki 1 mozlliwośc1 propagowanta literatury patryatyoznej 1 rozwój znajomośc1 myśl wozesnochrześcijańskiej polsce okresu Odrodzenia.

\section{Czesław Mazur - Warszawa}

\section{DIE PATRISTISChi LITERATUR IN POLEN WMHREND DER RENAISSANCE 1. ENTW ICKLUNGSBEDINGUNGEN /Zus ammenfassung/}

In den vorhandenen Monographien aber die Geschichte der Patrologie In Polon wird die lenalsancezelt besonders hervorgehoben; es fehlt jedoch an detallilerteren Arbeiten zu diesem Thema. In diesem Te11 des Artikels wurde versuont, die Bedingungen der Kenntinis der Sohriften der Kirchenviter bel uns zu bestimmen, und zwar auf der In thren Zusamenhlingen mit den Myglichkeiten der Verbreitung der patristisohen Literatur.

Den zweifellos sturksten Einfluss dbte hier die damalige allgemeineuropalsche Stromung aus, die als Humanismus bezelchnet ird, welohe nicht nur eine Renaissance der Studien tber die Denkmiler der antiken Kultur mit sich brachte, sondern auch oine Renaisance der Studien tber die patristische Literatur. Das propagierte Ideal der "Dreispraohigke1t" bew1rkte, dass man die in Polen bisher unbekannte griechisohe Sprache zu lehren begann, um ein unmittelbares Studium der Texte der griechisohen Kirchenviter zu ermygliche. Das wachsende Interesse an den Texten der Kirchenvater war auch von den Reformationsetr bmungen bedingt, vor allem wegen der Ausnutzung der Autoritat der vater in den religiösen Polemiken. Das machte ein genaueres Kennenlernen threr Sohriften notwend1g. Das vom Humanismus geweokte Interesse an der patristisohen Literatur wurde durch die Repormation also noch gestlurkt.

Auch elnige Erelgnisse der damaligen Zeit hatten direkten Einfluss aup das zunehmende Interesse an der patristischen Literatur.
Am 15. Juli 1568 verkandete Papst Plus V. die Bulle "Quod a nobis" und verlieh vier grieeohisohen vatern den Titel "Doktor der Kirche". was auch in Polen ein Eoho fand. Besondere Bedeutung kam hier jedoch 
dem Tridentinischen Konzil zu, das den Rang der patristischen Tradition im Verhlitis zur Heiligen Sohrift und der gesamten Tradition der Kirche bestimmte. Die Lektüre der Sohriften der Kirchenvater wurde in Form von Anwe1sungen auch von den polntschen K1rchensynoden emprohlen /z.B. 1527 in Leczyoa und 1542 in Plotrkóm/.

Alle diese Moglichkelten, die die neue Epoche zur Verbreitung der Sohriften der Kirchenviter mit sich brachte, konnten hauptelchlioh dank dor Einfuhrung des Buohdrucks genutzt werdon. In den orsten Ihr Firken in Polen beginnenden typographischen Werketatten begann. man sofort auch die Sohriften der Kirchenviter zu drucken. Grosse Bedeutung hatten auch die damaligen "Humanistenwanderungen", d, $h$. d1e zahlreichen internationalen 1 issenschaftlichen Kontakte der Polen, Studienreisen und Auslandsstudien, besonders in Italien /Padua, Rom/ und Basel. Das begllnstigte auoh die Einfuhr von Schriften der Kirohenvater, die in den europdischen Verlagshaugern gedruokt wurden, nach Polen.

All dies schup reale Moglichkeiten fur die Entwicklung der patristisohen Studien auch in Polen. 